\title{
Metals Complexes Formed with Oleanolic Acid
}

\author{
Nilton C. Ribeiro ${ }^{1,2}$, Antonio J. Demuner ${ }^{1}$, Marcelo H. dos Santos ${ }^{1}$, Célia R. A. Maltha ${ }^{1}$, \\ Elson A. de Alvarenga ${ }^{1}$, Slavko Komarnytsky ${ }^{3}$
}

\author{
${ }^{1}$ Chemistry Department, Universidade Federal de Viçosa, Avenida Peter Henry Rolfs, s/n Campus Universitário, \\ Viçosa, Minas Gerais, Brazil \\ ${ }^{2}$ IFMT, Rondonópolis, Brazil \\ ${ }^{3}$ North Carolina State University, Research Campus, Kannapolis, NC, USA \\ Email: nilton.ribeiro@roo.ifmt.edu.br
}

How to cite this paper: Ribeiro, N.C., Demuner, A.J., dos Santos, M.H., Maltha, C.R.A., de Alvarenga, E.A. and Komarnytsky, S. (2018) Metals Complexes Formed with Oleanolic Acid. International Journal of Organic Chemistry, 8, 160-169.

https://doi.org/10.4236/ijoc.2018.81011

Received: January 30, 2018

Accepted: March 9, 2018

Published: March 12, 2018

Copyright () 2018 by authors and Scientific Research Publishing Inc. This work is licensed under the Creative Commons Attribution International License (CC BY 4.0).

http://creativecommons.org/licenses/by/4.0/

\begin{abstract}
The oleanolic acid possesses diverse pharmacological properties, it is considered as a good starting material for creating new compounds. The oleanolic acid isolated of Plumeria obtusa leaves was used as raw material to obtained calcium, magnesium, zinc, nickel and copper complexes. The structures of complexes were confirmed by HRMS, ${ }^{1} \mathrm{H}$ NMR, and ${ }^{13} \mathrm{C}$ NMR. Five new compounds were synthesized to promote increased biological activity of oleanolic acid and PCR assays for the different type of cancer.
\end{abstract}

\section{Keywords \\ Oleanolic Acid, Complex, PCR}

\section{Introduction}

Oleanolic acid $(\mathrm{OA})$ is a pentacyclic triterpenoid that occurs naturally in several plants either as a free acid or as an aglycone of saponins [1]. OA is found in high concentrations in the leaves, fruits, and oil of Olea europaea L. [2] [3]. OA can be extracted from apples [4] or plants such as the Plumeria obtuse [5]. OA has been extracted from more than 1620 different plant species and used for food and medicinal purposes [6]. OA has gained significant interest, and several studies have demonstrated the importance of its use in hepatoprotective [7] [8], anti-inflammatory [7] [8], and anticancer activities [9]. OA is also a phosphorylase inhibitor [10]. In China, OA has been used orally to treat liver disorders [11], and it is a registered drug used intravenously in the treatment of hepatitis B and liver cancer [12].

Since OA possesses diverse pharmacological properties, it is considered as a good starting material for creating new compounds [13]. OA comprises three 
active points: C3, where hydroxyl is stored; the double bonds present in the ring between the $\mathrm{C} 12$ and $\mathrm{C} 13$ carbons; and $\mathrm{C} 28$, where carboxylic acid is stored (Figure 1); these points enable modifications, which lead to the creation of new chemical compounds [14] [15].

However, OA has limited bioavailability and does not provide a good plasma half-life because of its low solubility in water [16] [17]. Several studies have demonstrated that the structural alterations in OA can have a significant impact on biological activities [18]. The improvements in biological activities, such anti-inflammatory, antidiabetic, nephropathy, and cytotoxicity, have been achieved by changing some points in the OA structure [19] [20]. Terpenes complexes were very effective in several diseases [21].

Tabrizi et al. [22] showed that ruthenium (II) p-cymene complexes of naphthoquinone derivatives worked powerfully to combat melanomas in humans. Ghosh et al. [23] demonstrated the antioxidant activity of the quercetin-magnesium complex, and similar benefits were recorded for the complexation of copper with quercetin. The use of the bactericidal properties of calcium and copper complexes against Gram-positive bacteria has also been demonstrated [24].

Taking into consideration the aforementioned and potential medical uses of $\mathrm{OA}$ and its derivatives, five new compounds were synthesized using the OA.

\section{Experimental}

\subsection{General Procedures and Equipment}

The ${ }^{1} \mathrm{H}$ and ${ }^{13} \mathrm{C}$ experiments were performed on a Bruker 600-MHz NMR spectrometer equipped with an AVANCE III console, and a DCH cryogenically cooled probe. The conditions for ${ }^{1} \mathrm{H}$ experiments were as follows: Bruker pulse sequence $=\mathrm{zg} 30$; the number of acquisition points $=65,536$; the number of acquisitions $=128$; sweep width $=20.55 \mathrm{ppm}$; recycle delay $=2 \mathrm{~s}$; frequency $=$ $600.13 \mathrm{MHz}$. The conditions for ${ }^{13} \mathrm{C}$ experiments were as follows: Bruker pulse sequence $=$ zgpg 30 ; the number of acquisition points $=65,536$; the number of

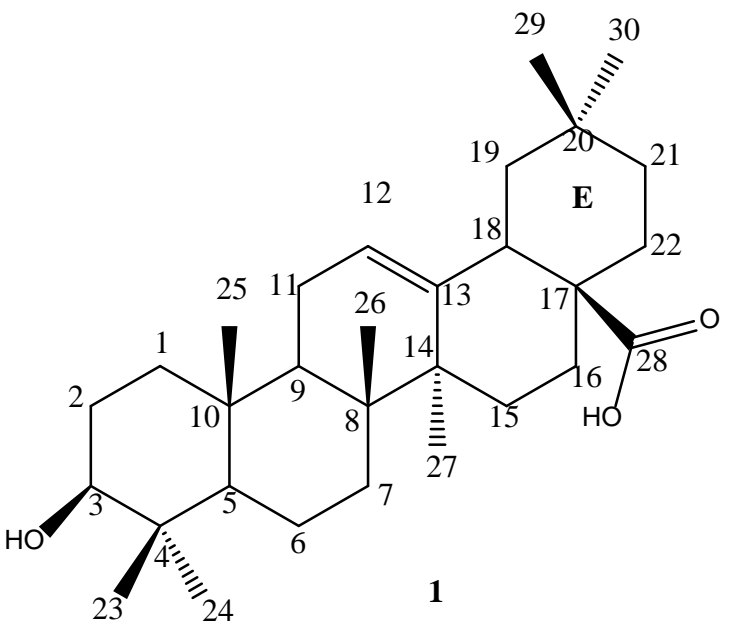

Figure 1. Molecular structure of oleanolic acid. 
acquisitions $=4096$; sweep width $=238.9 \mathrm{ppm}$; recycle delay $=2 \mathrm{~s}$; frequency $=$ 150.9 MHz. Deuterated methanol, $\mathrm{CD}_{3} \mathrm{OD}$, was used as the solvent.

The IR spectra were recorded on a Perkin Elmer Paragon 1000 FTIR spectrophotometer in the ATR mode over the range $400-4000 \mathrm{~cm}^{-1}$.

The analyses were performed on LC-MS-QTOF-6530 model L-1200 (Agilent brand) with the software Profinder series B.06.00; flow: $0.6 \mathrm{~mL} / \mathrm{min}-\mathrm{C} 18$ column $-1.8 \mu \mathrm{M}, 3 \mathrm{~mm} \times 100 \mathrm{~mm}$. The mobile phase A: $0.1 \%$ formic acid in water, mobile phase B: $0.1 \%$ formic acid in acetonitrile.

\subsection{Isolation of Oleanolic Acid}

The leaves of Plumeria alba were collected and dried in a greenhouse, after drying were submitted to extraction with ethanol in the ratio 6:1 solvent for the sample. After 7 days, the material was filtered, and the solvent was removed using reduced pressure. The sample was subjected to the silica gel $60(0.063-0.2$ $\mathrm{mm} / 70$ - 230 mesh ASTM) filter column [25] [26] (Macherey-Nagel, Germany) and fractionated with one liter of each of the following eluents: hexane, dichloromethane, ethyl acetate, methanol, and water. The solutions obtained were concentrated and analyzed by CCD. The pre-selected extracts were subjected to classical silica gel chromatography and Sephadex ${ }^{\otimes}$ LH-20 for the isolation and purification of compounds.

\subsection{Melting Temperature}

The melting temperatures were determined on MQAPF 320 equipment from Microquímica Equipamentos Ltda.

\subsection{Complex Reaction}

A round bottom flask $(500 \mathrm{~mL})$ was charged with 1 equivalent of metal sulfate to 2 equivalent of $\mathrm{OA}$ and $300 \mathrm{~mL}$ methanol. The resulting reaction mixture was vigorously stirred at $57^{\circ} \mathrm{C}$ for 6 hours. The solution was cooled to room temperature, and the methanol was removed using reduced pressure to obtain the compounds (Figure 1) [27]. The material was measured and calculated the yield the reaction.

\subsection{RNA Extraction and qPCR}

Total RNA was isolated from H4IIE cells or from tissue from rats maintained with liquid nitrogen, using the TRIzol reagent (Life Technologies). The total RNA was isolated from cells using TRIzol reagent (Life Technologies). RNA was quantified using Synergy H1/Take 3 plate setup (BioTek). The cDNAs were synthesized using $2 \mu \mathrm{g}$ of RNA for each sample using high-capacity cDNA Reverse Transcription kit (Life Technologies) on an ABI GeneAMP 9700 (Life Technologies).

The resulting CDNA was amplified in duplicate by real-time quantitative PCR (qPCR) using SYBR green PCR Master Mix (Life Technologies). To avoid interference due to genomic DNA contamination, only intron-overlapping primers 
were selected using the Primer Express version 2.0 software (Applied Biosystems, Foster City, CA) as follows: $\beta$-actin (housekeeping gene), forward primer: 5'-GGG AAA TCG TGC GTG ACA TT-3', reverse primer: 5'-GCG GCA GTG GCC ATC TC-3'; G6Pase, forward primer: 5'-TGT TCC TCT TAA TCC TGC CCA-3', reverse primer: 5'-CCA ACC TGC ACA AGT TCC CTT-3'. qPCR amplifications were performed on an ABI 7500 Fast real-time PCR (Life Technologies) using 1 cycle at $50^{\circ} \mathrm{C}$ for $2 \mathrm{~min}$ and 1 cycle of $95^{\circ} \mathrm{C}$ for $10 \mathrm{~min}$, followed by 40 cycles of $15 \mathrm{~s}$ at $95^{\circ} \mathrm{C}$ and $1 \mathrm{~min}$ at $60^{\circ} \mathrm{C}$. The dissociation curve was completed with $1 \mathrm{cycle}$ of $1 \mathrm{~min}$ at $95^{\circ} \mathrm{C}, 30 \mathrm{~s}$ at $55^{\circ} \mathrm{C}$, and $30 \mathrm{~s}$ at $95^{\circ} \mathrm{C}$. mRNA expression was analyzed using the $\triangle \Delta \mathrm{CT}$ method, and normalized concerning the expression of the $\beta$-actin using ABI 7500 Fast System SDS Software v1.3.0 (Life Technologies). Amplification of specific transcripts was further confirmed by obtaining melting curve profiles. All results were expressed as fold change from the induced Dex-cAMP controls. For the assays, samples at the concentration of $5.0 \mathrm{mg} / 100 \mu \mathrm{l}$ were used with $5.0 \mu \mathrm{l}$ of the cDNA.

\section{Results and Discussion}

After the use of three chromatographic columns with different mobile phases and monitoring the separation with thin layer chromatography and with the developers phosphomolybdic acid and vanillin, the oleanolic acid compound was obtained, where it was confirmed according to the ${ }^{13} \mathrm{C}$ and ${ }^{1} \mathrm{H}$ NMR data in Table 1 .

The synthesized compounds were analyzed using the NMR technique, and the ${ }^{13} \mathrm{C}$ and ${ }^{1} \mathrm{H}$ data for OA were initially obtained for comparison with the NMR data of the compounds.

The results in Table 1 show that $\mathrm{C} 28$ for the compounds with $\mathrm{Ca}, \mathrm{Mg}, \mathrm{Cu}, \mathrm{Zn}$, and $\mathrm{Ni}$ has a different displacement value compared to that obtained with OA. Considering C28 as one of the possible reaction points [14] [15], and the data obtained by the IR technique which show the absence of the band for carboxylic acid bound to $\mathrm{C} 28$, it is clear that the reaction is formed together with a carboxylic acid group. It is still possible to discern a small variation in the displacement of the $\mathrm{C} 12$ and $\mathrm{C} 13$ carbons and those carrying the double bond. This suggests that electron displacement is promoted by the withdrawal effect exerted by both metals when they are bound to the hydroxyl oxygen of the carboxylic acid group.

The structures of the synthesized compounds are also supported by the following data.

$\mathrm{C}_{30} \mathrm{H}_{48} \mathrm{O}_{3}$ (Oleanolic acid) White solid, $0.621 \mathrm{~g}$ of the pure compound, m.p. $307^{\circ} \mathrm{C}-309^{\circ} \mathrm{C}$, IR (ATR) $v_{\max } / \mathrm{cm}^{-1}: 3455,3048,2932,2859,1689,1460,1382$, 1271, 1031, 954, 658.

$\mathrm{C}_{60} \mathrm{H}_{94} \mathrm{CaO}_{6}$ It was obtained in $71 \%$ yield $(0.1150 \mathrm{~g}, 0.1209 \mathrm{mmol})$ via reaction of the 1.0 eq. of calcium sulfate to 2.0 eq. of oleanolic acid. White solid, IR (ATR) $v_{\max } / \mathrm{cm}^{-1}: 3370,2928,2865,1537,1465,1387,1136,1029,995$. LC-MS $[\mathrm{M}+\mathrm{H}]^{+}$calculate for $\mathrm{C}_{60} \mathrm{H}_{95} \mathrm{CaO}_{6}: 951.6755$, found 951.6750 . 
Table $1 .{ }^{1} \mathrm{H}$ and ${ }^{13} \mathrm{C}$ NMR chemical shifts to OA and complexes $(\delta \text {, ppm })^{\text {a }}$-oleanolic acid isolated.

\begin{tabular}{|c|c|c|c|c|c|c|c|c|c|c|c|c|}
\hline \multirow[b]{2}{*}{$\mathrm{C}$} & \multicolumn{2}{|c|}{$\mathrm{OA}^{\mathrm{a}}$} & \multicolumn{2}{|c|}{$\mathrm{Ca}-\mathrm{OA}$} & \multicolumn{2}{|c|}{$\mathrm{Mg}-\mathrm{OA}$} & \multicolumn{2}{|c|}{$\mathrm{Cu}-\mathrm{OA}$} & \multicolumn{2}{|c|}{$\mathrm{Zn}-\mathrm{OA}$} & \multicolumn{2}{|c|}{$\mathrm{Ni}-\mathrm{OA}$} \\
\hline & $\delta \mathrm{C}$ & $\delta \mathrm{H}$ & $\delta \mathrm{C}$ & $\delta \mathrm{H}$ & $\delta \mathrm{C}$ & $\delta \mathrm{H}$ & $\delta \mathrm{C}$ & $\delta \mathrm{H}$ & $\delta \mathrm{C}$ & $\delta \mathrm{H}$ & $\delta \mathrm{C}$ & $\delta \mathrm{H}$ \\
\hline 1 & 38.43 & 0.99 & 38.44 & 1.01 & 38.44 & 1.02 & 38.43 & 1.00 & 38.44 & 0.99 & 38.44 & 0.98 \\
\hline 2 & 26.47 & 1.79 & 26.49 & 1.75 & 26.49 & 1.77 & 26.46 & 1.76 & 26.47 & 1.77 & 26.5 & 1.75 \\
\hline 3 & 78.32 & 3.33 & 78.41 & 3.33 & 78.34 & 3.33 & 78.32 & 3.33 & 78.36 & 3.33 & 78.41 & 3.33 \\
\hline 4 & 38.43 & - & 38.48 & - & 38.44 & - & 39.02 & - & 38.47 & - & 38.49 & - \\
\hline 5 & 55.36 & 0.84 & 55.45 & 0.89 & 55.41 & 0.89 & 55.38 & 0.88 & 55.4 & 0.89 & 55.57 & 0.87 \\
\hline 6 & 18.10 & 1.41 & 18.17 & 1.58 & 18.18 & 1.57 & 18.16 & 1.59 & 18.17 & 1.59 & 18.18 & 1.58 \\
\hline 7 & 32.41 & 1.57 & 32.78 & 1.53 & 32.81 & 1.54 & 32.78 & 1.53 & 32.81 & 1.55 & 32.8 & 1.53 \\
\hline 8 & 39.16 & - & 39.13 & - & 39.18 & - & 39.12 & - & 39.11 & - & 39.13 & - \\
\hline 9 & 48.01 & 1.71 & 48.02 & 1.72 & 48.02 & 1.71 & 48.01 & 1.72 & 48.03 & 1.71 & 48.01 & 1.72 \\
\hline 10 & 36.77 & - & 36.81 & - & 36.82 & - & 36.81 & - & 36.8 & - & 36.82 & - \\
\hline 11 & 22.56 & 1.92 & 22.94 & 1.93 & 22.88 & 1.91 & 22.83 & 1.93 & 22.9 & 1.92 & 22.98 & 1.93 \\
\hline 12 & 122.26 & 5.26 & 121.08 & 5.23 & 121.21 & 5.22 & 121.2 & 5.24 & 121.16 & 5.25 & 120.96 & 5.23 \\
\hline 13 & 143.81 & - & 145.25 & - & 145.18 & - & 145.25 & - & 145.29 & - & 145.39 & - \\
\hline 14 & 41.49 & - & 42.06 & - & 41.87 & - & 41.78 & - & 41.77 & - & 42.13 & - \\
\hline 15 & 27.33 & 1.18 & 27.38 & 1.16 & 27.38 & 1.17 & 27.4 & 1.17 & 27.52 & 1.18 & 27.39 & 1.16 \\
\hline 16 & 22.65 & 2.03 & 23.16 & 1.93 & 23.17 & 1.91 & 23.03 & 1.94 & 23.05 & 1.95 & 23.17 & 1.93 \\
\hline 17 & 46.23 & - & 46.77 & - & 46.71 & - & 46.75 & - & 47.01 & - & 46.78 & - \\
\hline 18 & 41.33 & 3.17 & 41.62 & 3.32 & 41.68 & 3.32 & 41.72 & 3.32 & 41.73 & 3.31 & 41.64 & 3.28 \\
\hline 19 & 45.84 & 1.74 & 46.77 & 1.87 & 46.71 & 1.69 & 46.77 & 1.88 & 46.64 & 1.87 & 46.85 & 1.85 \\
\hline 20 & 30.20 & - & 30.40 & - & 30.38 & - & 30.36 & - & 30.38 & - & 30.43 & - \\
\hline 21 & 33.50 & 1.43 & 34.12 & 1.44 & 34.06 & 1.44 & 33.96 & 1.43 & 33.4 & 1.45 & 34.18 & 1.44 \\
\hline 22 & 32.15 & 1.76 & 32.54 & 1.87 & 32.44 & 1.74 & 32.42 & 1.88 & 32.54 & 1.87 & 32.6 & 1.87 \\
\hline 23 & 27.43 & 0.96 & 27.87 & 1.14 & 27.75 & 1.33 & 27.71 & 1.13 & 27.72 & 1.12 & 27.91 & 1.14 \\
\hline 24 & 14.90 & 0.93 & 14.92 & 1.093 & 14.96 & 1.03 & 14.97 & 1.09 & 15.08 & 1.08 & 14.94 & 1.09 \\
\hline 25 & 14.47 & 0.84 & 14.50 & 0.96 & 14.54 & 0.99 & 14.52 & 0.98 & 14.57 & 0.97 & 14.51 & 0.96 \\
\hline 26 & 16.31 & 0.80 & 16.79 & 1.097 & 17.00 & 0.90 & 17.00 & 1.09 & 17.02 & 1.08 & 16.84 & 1.07 \\
\hline 27 & 24.98 & 1.34 & 25.08 & 1.34 & 25.04 & 1.35 & 25.03 & 1.35 & 25.14 & 1.36 & 25.12 & 1.37 \\
\hline 28 & 180.43 & - & 184.45 & - & 185.65 & - & 187.63 & - & 187.89 & - & 184.82 & - \\
\hline 29 & 32.61 & 1.33 & 32.99 & 0.79 & 33.21 & 0.96 & 33.06 & 0.78 & 33.03 & 0.78 & 33.05 & 0.78 \\
\hline 30 & 23.11 & 0.92 & 23.16 & 0.99 & 23.20 & 0.80 & 23.13 & 0.99 & 23.15 & 0.99 & 23.2 & 0.99 \\
\hline
\end{tabular}

$\mathrm{C}_{60} \mathrm{H}_{94} \mathrm{MgO}_{6}$ It was obtained in $68 \%$ yield $(0.1120 \mathrm{~g}, 0.1198 \mathrm{mmol})$ via reaction of the 1.0 eq. of magnesium sulfate to 2.0 eq. of oleanolic acid. White solid, IR (ATR) $v_{\max } / \mathrm{cm}^{-1}: 3244,2926,1526,1385,1089,1029,771$. LC-MS $[\mathrm{M}+\mathrm{H}]^{+}$ calculate for $\mathrm{C}_{60} \mathrm{H}_{95} \mathrm{MgO}_{6}$ : 935.6979, found 935.6976 [28]. 
$\mathrm{C}_{60} \mathrm{H}_{94} \mathrm{CuO}_{6}$ It was obtained in $70 \%$ yield $(0.0989 \mathrm{~g}, 0.1015 \mathrm{mmol})$ via reaction of the 1.0 eq. of copper sulfate to 2.0 eq. of oleanolic acid. Green solid, IR (ATR) $v_{\max } / \mathrm{cm}^{-1}: 3395,2938,2862,1537,1386,1094,995,728$. LC-MS $[\mathrm{M}+\mathrm{H}]^{+}$calculate for $\mathrm{C}_{60} \mathrm{H}_{94} \mathrm{CuO}_{6}: 973.6346$, found 973.6344 .

$\mathrm{C}_{60} \mathrm{H}_{94} \mathrm{ZnO}_{6}$ It was obtained in $68 \%$ yield $(0.101 \mathrm{~g}, 0.1036 \mathrm{mmol})$ via reaction of the 1.0 eq. of zinc sulfate to 2.0 eq. of oleanolic acid. White solid, IR (ATR) $v_{\max } / \mathrm{cm}^{-1}: 3299,2940,2864,1595,1461,1084,736,677$. LC-MS $[\mathrm{M}+\mathrm{H}]^{+}$calculate for $\mathrm{C}_{60} \mathrm{H}_{94} \mathrm{ZnO}_{6}$ : 974.6342, found 974.6341 .

$\mathrm{C}_{60} \mathrm{H}_{94} \mathrm{NiO}_{6}$ It was obtained in $69 \%$ yield $(0.0899 \mathrm{~g}, 0.0928 \mathrm{mmol})$ via reaction of the 1.0 eq. of nickel sulfate to 2.0 eq. of oleanolic acid. Green solid, IR (ATR) $v_{\max } / \mathrm{cm}^{-1}: 3320,2928,2863,1534,1453,1373,1029,772$. LC-MS $[\mathrm{M}+\mathrm{H}]^{+}$calculate for $\mathrm{C}_{60} \mathrm{H}_{94} \mathrm{NiO}_{6}$ : 968.6404, found 968.6401 .

The shift in displacement promoted by the bonding between the metal $(\mathrm{Ca} / \mathrm{Mg} / \mathrm{Zn} / \mathrm{Ni} / \mathrm{Cu})$ with the oxygen of the hydroxyl at $\mathrm{C} 28$ indicates the formation of that new bond.

The stretch $v\left(\mathrm{C}=\mathrm{O}\right.$ ) at $\mathrm{C} 28$ at $1691 \mathrm{~cm}^{-1}$ (Figure 2) present to $\mathrm{OA}$ is absent in the IR spectra for all complex formed. Also shows the absence of characteristic stretching $v(\mathrm{C}=\mathrm{O})$ band in the wave-number region between $1715-1680 \mathrm{~cm}^{-1}$, and the absence of band resulting from the angular deformation of the $v(\mathrm{OH})$ bond of the carboxylic acid in the region between $955-875 \mathrm{~cm}^{-1}$ [29]. However, these bands are present in the IR spectrum of OA and reinforce the formation of the complex; therefore, five new complexes with OA are created.

As shown (Figure 3 ) it is possible to identify the formation of the complexes with the metal and OA, the bond between the metal and the oxygen atom promotes a displacement of electrons, in this way the NMR values (Table 1) increase, such as the values obtained for C28. The same bond, suppresses the band obtained in $1689 \mathrm{~cm}^{-1}$ for OA in the IR experiments.

The fold change values show the activity of the compounds isolated in trials where three different genes were used (Table 2). The compound synthesized

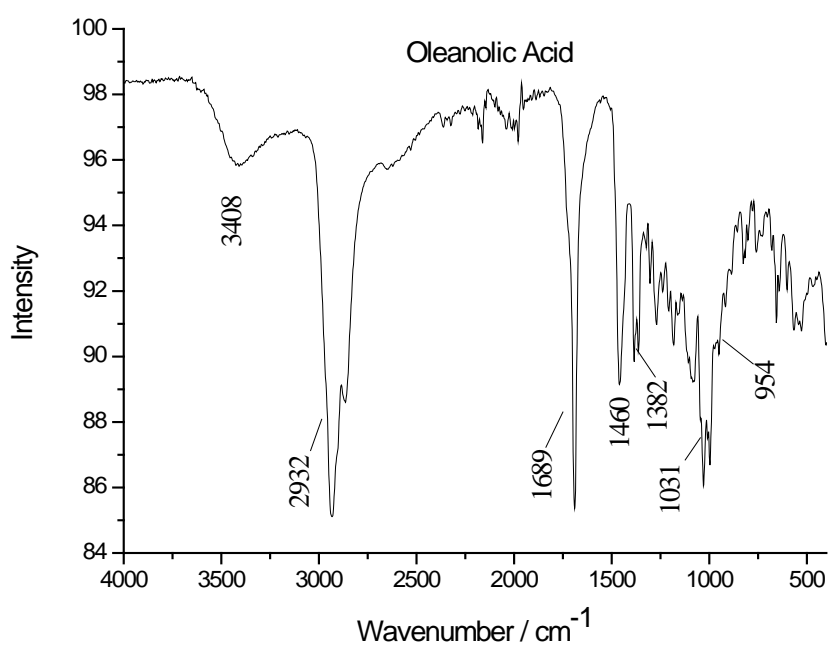

Figure 2. The infrared spectrum of oleanolic acid. 


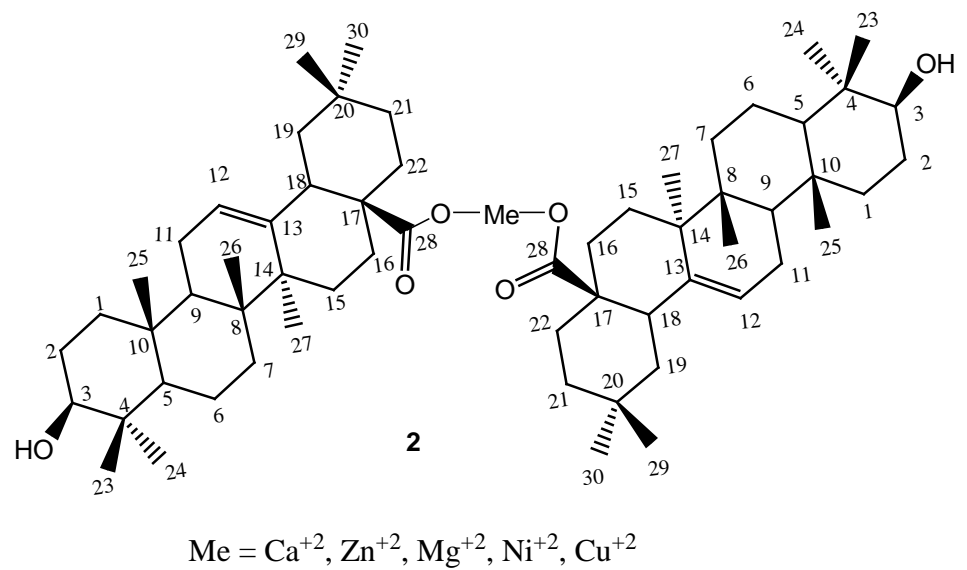

Figure 3. The molecular structure of the complex formed with calcium, magnesium, copper, zinc, and nickel with oleanolic acid.

Table 2. Results of PCR assays for the complexes of calcium, magnesium, and oleanolic acid.

\begin{tabular}{cccc}
\hline Amostras & G6P & PEPCK & FAS \\
\hline Oleanolic acid & 3.6 & 3.9 & 1.8 \\
Complex Ca & 0.8 & 0.9 & 1.1 \\
Complex $\mathrm{Mg}$ & 9.0 & 6.5 & 3.9 \\
Complex Cu & 0.1 & 0.6 & 0.3 \\
Complex Zn & 0.0 & 0.5 & 0.9 \\
Complex Ni & 0.7 & 0.4 & 0.6 \\
\hline
\end{tabular}

from oleanolic acid and calcium showed little efficiency in the control of these genes, presenting lower values when compared to pure oleanolic acid, that is, there was a decrease in the biological activity of the synthesized compound. Different results were obtained for the compound formed from oleanolic acid and magnesium; the values were higher than the result of the pure oleanolic acid and the compound formed with calcium. Greater success was achieved with the G6P gene reaching a fold change value close to 9.0, for the PEPCK gene, there is also a significant value. Not being so effective for the FAS gene [30] [31].

\section{Conclusion}

Five novel compounds were synthesized using OA as starting material, the novel and inedited structures were confirmed by NMR, IR and LC-MS experiments. The NMR, IR, and LC-MS data support the literature data for the passive points of reactions in the OA molecule. Among the five new compounds synthesized, the complex formed with magnesium, showed better results for the tests performed.

\section{References}

[1] Liu, J. (1995) Pharmacology of Oleanolic Acid and Ursolic Acid. Journal of Ethno- 
pharmacology, 49, 57-68. https://doi.org/10.1016/0378-8741(95)90032-2

[2] Jäger, S., Trojan, H., Kopp, T., Laszczyk, M.N. and Scheffler, A. (2009) Pentacyclic Triterpene Distribution in Various Plants-Rich Sources for a New Group of Multi-Potent Plant Extracts. Molecules, 14, 2016-2031.

https://doi.org/10.3390/molecules14062016

[3] Shanmugam, M.K., Dai, X., Kumar, A.P., Tan, B.K.H., Sethi, G. and Bishayee, A. (2014) Oleanolic Acid and Its Synthetic Derivatives for the Prevention and Therapy of Cancer: Preclinical and Clinical Evidence. Cancer Letters, 346, 206-216. https://doi.org/10.1016/j.canlet.2014.01.016

[4] He, X. and Rui, H.L. (2007) Triterpenoids Isolated from Apple Peels Have Potent Antiproliferative Activity and May Be Partially Responsible for Apple's Anticancer Activity. Journal of Agricultural and Food Chemistry, 55, 4366-4370. https://doi.org/10.1021/jf063563o

[5] Gambhava, N.S., Ezhava, S.B., Rathod, I.S., Chhabria, M.T. and Patwari, A.H. (2013) Estimation of Ursolic Acid and Oleanolic Acid from Leaves of Plumeria Obtuse by HPTLC Method after Iodine Derivatization. Der Pharma Chemica, 5, 44-50.

[6] Ovesna, Z., Kozics, K. and Slamenova, D. (2006) Protective Effects of Ursolic Acid and Oleanolic Acid in Leukemic Cells. Mutation Research/Fundamental and Molecular Mechanisms of Mutagenesis, 600, 131-137. https://doi.org/10.1016/j.mrfmmm.2006.03.008

[7] Lee, W., Yang, E.J., Ku, S.K., Song, K.S. and Bae, J.S. (2013) Anti-Inflammatory Effects of Oleanolic Acid on LPS-Induced Inflammation in vitro and in vivo. Inflammation, 36, 94-102. https://doi.org/10.1007/s10753-012-9523-9

[8] Hsu, H.Y., Yang, J.J. and Lin, C.C. (1997) Effects of Oleanolic Acid and Ursolic Acid on Inhibiting Tumor Growth and Enhancing the Recovery of Hematopoietic System Postirradiation in Mice. Cancer Letters, 111, 7-13. https://doi.org/10.1016/S0304-3835(96)04481-3

[9] Mengoni, F., Lichtner, M., Battinelli, L., Marzi, M., Mastroianni, C.M., Vullo, V., et al. (2002) In vitro Anti-HIV Activity of Oleanolic Acid on Infected Human Mononuclear Cells. Planta Medica, 68, 111-114. https://doi.org/10.1055/s-2002-20256

[10] Dzubak, P., Hajduch, M., Vydra, D., Hustova, A., Kvasnica, M., Biedermann, D., et al. (2006) Pharmacological Activities of Natural Triterpenoids and Their Therapeutic Implications. Natural Product Reports, 23, 394-411. https://doi.org/10.1039/b515312n

[11] Liu, J. (2005) Oleanolic Acid and Ursolic Acid: Research Perspectives. Journal of Ethnopharmacology, 100, 92-94. https://doi.org/10.1016/j.jep.2005.05.024

[12] Chen, J., Gong, Y., Liu, J., Hua, W., Zhang, L. and Sun, H. (2008) Synthesis and Biological Evaluation of Novel-Pyrazolo [4,3-b] Oleanane Derivatives as Inhibitors of Glycogen Phosphorylase. Chemistry and Biodiversity, 5, 1304-1312. https://doi.org/10.1002/cbdv.200890117

[13] Place, A.E., Suh, N., Williams, C.R., Risingsong, R., Honda, T., Honda, Y., et al. (2003) The Novel Synthetic Triterpenoid, CDDO-Imidazolide, Inhibits Inflammatory Response and Tumor Growth in vivo. Clinical Cancer Research, 9, 2798-2806.

[14] Bednarczyk-Cwynar, B., Zaprutko, L., Ruszkowski, P. and Hładoń, B. (2012) Anticancer Effect of A-Ring or/and C-Ring Modified Oleanolic Acid Derivatives on KB, MCF-7 and HeLa Cell Lines. Organic \& Biomolecular Chemistry, 10, 2201-2205. https://doi.org/10.1039/c2ob06923g 
[15] Garcia-Granados, A., López, P.E., Melguizo, E., Parra, A. and Simeó, Y. (2006) Reactivity of Chiral Sesquiterpene Synthons Obtained by the Degradation of Maslinic Acid from Olive-Pressing Residues. Synthetic Communications, 36, 3001-3018. https://doi.org/10.1080/00397910600773858

[16] Chen, H., Gao, Y., Wang, A., Zhou, X., Zheng, Y. and Zhou, J. (2015) Evolution in Medicinal Chemistry of Ursolic Acid Derivatives as Anticancer Agents. European Journal of Medicinal Chemistry, 92, 648-655. https://doi.org/10.1016/j.ejmech.2015.01.031

[17] Zhang, H., Li, X., Ding, J., Xu, H., Dai, X., Hou, Z., et al. (2013) Delivery of Ursolic Acid (UA) in Polymeric Nanoparticles Effectively Promotes the Apoptosis of GASTRIC CANCER CELLs through Enhanced Inhibition of Cyclooxygenase 2 (COX-2). International Journal of Pharmaceutics, 441, 261-268. https://doi.org/10.1016/j.ijpharm.2012.11.034

[18] Acebey-Castellon, I.L., Voutquenne-Nazabadioko, L., Doan Thi Mai, H., Roseau, N., Bouthagane, N., Muhammad, D., et al. (2011) Triterpenoid Saponins from Symplocos Lancifolia. Journal of Natural Products, 74, 163-168. https://doi.org/10.1021/np100502y

[19] Masullo, M., Pizza, C. and Piacente, S. (2017) Oleanane Derivatives for Pharmaceutical Use: A Patent Review (2000-2016). Expert Opinion on Therapeutic Patents, 27, 237-255. https://doi.org/10.1080/13543776.2017.1253680

[20] Suh, N., Wang, Y., Honda, T., Gribble, G.W., Dmitrovsky, E., Hickey, W.F., et al. (1999) A Novel Synthetic Oleanane Triterpenoid, 2-Cyano-3,12-Dioxoolean-1,9-Dien-28-Oic Acid, with Potent Differentiating, Antiproliferative, and Anti-Inflammatory Activity. Cancer Research, 59, 336-341.

[21] Partal Ureña, F., Moreno, J.R.A. and López González, J.J. (2009) Conformational Study of $(R)-(+)$-Limonene in the Liquid Phase Using Vibrational Spectroscopy (IR, Raman, and VCD) and DFT Calculations. Tetrahedron: Asymmetry, 20, 89-97. https://doi.org/10.1016/j.tetasy.2009.01.024

[22] Tabrizi, L. and Chiniforoshan, H. (2016) Ruthenium(II) p-Cymene Complexes of Naphthoquinone Derivatives as Antitumor Agents: A Structure Activity Relationship Study. Journal of Organometallic Chemistry, 822, 211-220. https://doi.org/10.1016/j.jorganchem.2016.09.003

[23] Bukhari, S.B., Memon, S., Mahroof-Tahir, M. and Bhanger, M.I. (2009) Synthesis, Characterization and Antioxidant Activity Copper-Quercetin Complex. Spectrochimica Acta Part A: Molecular and Biomolecular Spectroscopy, 71, 1901-1906. https://doi.org/10.1016/j.saa.2008.07.030

[24] Jadeja, R.N., Vyas, K.M., Gupta, V.K., Joshi, R.G. and Ratna Prabha, C. (2012) Syntheses, Characterization and Molecular Structures of Calcium(II) and Copper(II) Complexes Bearing $\mathrm{O}_{2}$-Chelate Ligands: DNA Binding, DNA Cleavage and Anti-Microbial Study. Polyhedron, 31, 767-778. https://doi.org/10.1016/j.poly.2011.11.004

[25] Hench, L.L. and West, J.K. (1990) The Sol-Gel Process. Chemical Reviews, 90, 33-72. https://doi.org/10.1021/cr00099a003

[26] Tubert-Brohman, I., Sherman, W., Repasky, M. and Beuming, T. (2013) Improved Docking of Polypeptides with Glide. Journal of Chemical Information and Modeling, 53, 1689-1699.

[27] Manente, F.A., De Almeida Mello, L.R., Khalil, O.A.K., De Carvalho, C.T., Bannach, G. and Vellosa, J.C.R. (2011) Efeito da complexação de metais aos antiinflamatórios na ação contra agentes oxidativos e radicais livres: Ação do cetoprofeno. Ecletica 
Quimica, 36, 107-127. https://doi.org/10.1590/S0100-46702011000200006

[28] Novotny, L., Abdel-Hamid, M.E., Hamza, H., Masterova, I. and Grancai, D. (2003) Development of LC-MS Method for Determination of Ursolic Acid: Application to the Analysis of Ursolic Acid in Staphylea holocarpa Hemsl. Journal of Pharmaceutical and Biomedical Analysis, 31, 961-968. https://doi.org/10.1016/S0731-7085(02)00706-9

[29] Kalođera, Z. and Sofić, E. (2009) Identification and Isolation of Pharmacologically Active Triterpenes in Betula Cortex, Betula Pendula Roth., Betulaceae. Bosnian Journal of Basic Medical Sciences, 9, 31-38. https://doi.org/10.17305/bjbms.2009.2853

[30] Kim, H.J., Jee, H.J. and Yun, J. (2011) DNA Damage Induces Down-Regulation of PEPCK and G6P Gene Expression through Degradation of PGC-1. Acta Biochimica et Biophysica Sinica, 43, 589-594. https://doi.org/10.1093/abbs/gmr053

[31] Nordgren, J., Nitiema, L.W., Sharma, S., Ouermi, D., Traore, A.S., Simpore, J., et al. (2012) Emergence of Unusual G6P Rotaviruses in Children, Burkina Faso, 2009-2010. Emerging Infectious Diseases, 18, 589-597.

https://doi.org/10.3201/eid1804.110973 